\title{
ASUPAN KARBOHIDRAT HARIAN TERHADAP RISIKO KEJADIAN DIABETES MELITUS GESTASI (GDM) MELALUI GLYCO-HEMOGLOBIN IBU HAMIL
}

\author{
Def Primal $^{1}$, Tetra Anestasia Putri ${ }^{2}$, Wira Meiriza $^{3}$ \\ Universitas Perintis Indonesia ${ }^{1,3}$ \\ Akademi Bakti Kemanusiaan Palang Merah Indonesia ${ }^{2}$ \\ def.primal.anatomy@gmail.com ${ }^{1}$
}

\begin{abstract}
ABSTRAK
Penelitian ini bertujuan untuk mengidentifikasi keterkaitan jumlah asupan karbohidrat pada ibu hamil trimester ketiga dengan kejadian diabetes mellitus gestasional (GDM) di wilayah dinas kesehatan Kota Bukittinggi. Metode penelitian ini adalah penelitian cross sectional menggunakan pendekatan eksperimental. Hasil penelitian menunjukan asupan karbohidrat (gram) harian ibu hamil trimester ketiga memiliki hubungan yang bermakna terhadap kejadian GDM di wilayah kerja dinas kesehatan Kota Bukittinggi berdasarkan 34 orang ibu hamil yang telah diperiksa. Hal ini dapat dilihat dari semakin tinggi asupan karbohidrat harian ibu hamil, akan peningkatkan nilai persentase HbA1c. Simpulan, adanya keterkaitan asupan konsisten harian karbohidrat dengan nilai HbA1c yang mengacu kepada terjadinya status pre-diabetes dan diabetes gestasi pada ibu hamil trimester ketiga.
\end{abstract}

Kata Kunci: Asupan Karbohidrat, Gestational Diabetes Mellitus HbA1c

\section{ABSTRACT}

This study aims to identify the relationship between the amount of carbohydrate intake in pregnant women in the third trimester with the incidence of gestational diabetes mellitus (GDM) in the health office area of the City of Bukittinggi. This research method is a cross-sectional study using an experimental approach. The results showed that the daily intake of carbohydrates (grams) of pregnant women in the third trimester had a significant relationship with the incidence of GDM in the working area of the Bukittinggi City Health Office based on 34 pregnant women who had been examined. This can be seen from the higher the daily intake of carbohydrates for pregnant women, the increase in the percentage value of HbAlc. In conclusion, there is a correlation between the consistent daily intake of carbohydrates and the HbAlc weight, which refers to pre-diabetes status and gestational diabetes in the third trimester of pregnant women.

Keywords: Carbohydrate Intake, Gestational Diabetes Mellitus, HbAlc 


\section{PENDAHULUAN}

Gestational Diabetes Mellitus (GDM) atau diabetes mellitus kehamilan merupakan satu dari beberapa komplikasi medis yang paling sering terjadi pada masa kehamilan. Gangguan ini berpengaruh penting terhadap status kesehatan bagi ibu dan anak. Kondisi ini didefinisikan sebagai fenomena intoleransi glukosa (hiperglikemia) dengan onset atau terdeteksi selama proses kehamilan trimester akhir dan tidak kembali normal setelah melahirkan (Dong et al., 2021). Hasbullah menyatakan bahwa GDM berisiko meningkat dimulai sejak trimester ke-2 kehamilan. Gestational diabetes mellitus (GDM) mengalami paling banyak komplikasi umum kehamilan di Amerika Serikat (135.000 kasus/ tahun), mewakili rata-rata 3-8\% total kehamilan (Hasbullah et al., 2020). Dalam dua studi, kejadian GDM meningkat terus-menerus dari 4\% menjadi 6\% lebih. Data terbaru menunjukkan peningkatan kejadian GDM yang substansial pada wanita dari etnis Asia, Afro-amerika dan Hispanik. Laporan dari Kaiser Permanente Southern California Health System tahun 2011 menunjukkan bahwa kenaikan tingkat GDM terus berlanjut setiap tahunnya. Sedangkan di China, prevalensi GDM telah melebihi 10\% pada beberapa tahun terakhir ini (Dong et al., 2021).

Wanita dengan GDM memiliki peningkatan risiko morbiditas kehamilan, risiko sindroma hipertensi kehamilan, persalinan premature, persalinan dengan sesaria, trauma obstetric, peningkatan risiko IGT/Impaired Glucose Tollerant (gangguan toleransi glukosa), dan diabetes tipe-2 beberapa tahun setelah kehamilan. Anak dari wanita dengan GDM lebih cenderung mengalami peningkatan signifikan berat badan dan panjang badan fetus, gangguan metabolisme, hypoglycemia neonatal, obesitas dan berisiko IGT, serta diabetes pada usia dewasa awal nantinya (Rasmussen et al., 2020; Silva et al., 2021). Gestational diabetes mellitus (GDM) berpengaruh penting selama kehamilan (perinatal) karena memicu obesitas dan intoleransi glukosa kongenital (turunan). Ibu juga berisiko mengalami hipertensi kehamilan dan risiko tinggi diabetes mellitus sesudahnya. Mendiagnosis GDM secara tepat dapat menurunkan komplikasi perinatal, tetapi hanya sedikit faktor risiko dapat dihindari. Tes glukosa segera dapat menstratifikasi risiko diabetes jangka pendek dan selanjutnya uji glukosahemoglobin HbA1c dapat mendeteksi kontrol glikemia dari asupan karbohidrat yang memburuk sebagai penanda diabetes mellitus lanjutan (diabetes tipe-2) maupun diabetes kehamilan (Silva et al., 2021).

Pada kondisi sekarang, asupan makronutrien dimana karbohidrat yang berkorelasi dengan respon glukosa darah dan pola western diet dengan asupan tinggi daging merah, daging olahan, permen dan biji-bijian halus berkaitan dengan peningkatan risiko kejadian diabetes tipe-2 berdasarkan studi kohort prospektif sebagian besar sampel. Beberapa hasil penelitian juga menyebutkan bahwa pola asupan harian rendah karbohidrat total (LCD) dikarenakan asupan makanan tinggi lemak dan protein hewani selama kehamilan trimester pertama berhubungan erat dengan risiko terjadinya GDM (Dong et al., 2021; Rasmussen et al., 2020). Hasil studi (Stevanović-Silva et al., 2021) juga menyatakan bahwa nutrisi tinggi kalori karbohidrat (high-fat-high-sucrose/ HFHS) selama kehamilan akan mengacu kepada GDM dan berisiko tinggi berkembangnya komplikasi metabolic sepanjang hidupnya, terutama memicu peningkatan berat badan yang signifikan, intoleransi glukosa, berkembangnya karakteristik GDM, dan NAFLD (non-alcoholic fatty liver disease).

Selain itu, studi pola konservatif mendapatkan terjadinya peningkatan risiko IGT dan/atau diabetes tipe-2. Dalam studi kohort prospektif pada 1.698 wanita hamil di AS, wanita dengan GDM mengkonsumsi persentase energi yang lebih rendah dari 
karbohidrat dan persentase energi lebih tinggi dari lemak pada trimester kedua, namun persentase energi tinggi dari karbohidrat di trimester ketiga. Selain itu, studi (Hasbullah et al., 2020) menyatakan adanya keterkaitan yang erat antara glicemic index (GI) dan glicemic load (GL) ibu hamil dari karakteristik usia ibu, proporsi asupan karbihidrat tinggi, rendahnya asupan serat, dan ekonomi keluarga rendah. Hal tersebut sangat tergantung dengan pola makan, seperti kebiasaan, kesenangan, budaya, agama, taraf ekonomi dan alam. Sehingga faktor-faktor tersebut berpengaruh pada status gizi ibu (Mariana et al., 2018).

Hasil survey ibu hamil dari dua Puskesmas di Kota Bukittinggi, yaitu; Puskesmas Puskesmas Mandiangin, dan Puskesmas Rasimah Ahmad belum bisa menunjukan angka kejadian pasti GDM, sedangkan informasi kejadian GDM di wilayah kerja puskesmas tersebut dikatakan cukup banyak. Karena jarak yang berdekatan antara kedua puskesmas tersebut dan tingginya kepadatan penduduk di kedua lingkup wilayah kerja puskesmas tersebut, beberapa tenaga kesehatan sama-sama mengakui masih banyak ibu hamil yang tidak memeriksakan glukosa darah selama masa kehamilan secara periodik dikarenakan kondisi ekonomi, pengetahuan, kesibukan aktivitas pekerjaan, kesadaran dan akses menuju puskesmas. Ibu hamil terdiagnosis GDM juga menyatakan belum mengetahui faktor pencetus dan risiko yang akan ditimbul jika glukosa darah normal tidak dipertahankan. Ibu mengakui jika tenaga kesehatan dan kader selalu menyarankan untuk menjaga gizi seimbang selama kehamilan (menyeimbangkan asupan karbohidrat), tetapi ibu tetap makan sesuai asupan biasa keluarga sehari-hari.

\section{METODE PENELITIAN}

Penelitian ini merupakan experimental study dengan desain deskriptif analitik menggunakan pendekatan cross-sectional. Populasi penelitian adalah seluruh ibu hamil yang diperkirakan pada bulan Maret 2020 berada pada kehamilan trimester ketiga dengan jumlah sampel menggunakan total sampling sebanyak 34 orang berdasarkan teknik penentuan purposive sampling. Untuk memenuhi teknik purposive sampling yang digunakan. Pengambilan sampel harus merujuk kepada kriteria inklusi penelitian, yaitu; a) sampel yang bersedia menjadi responden melalui persetujuan mengisi inform concent, dan b) ibu hamil di trimester ketiga. Populasi yang tidak dijadikan sampel jika memenuhi kriteria eksklusi; a) ibu hamil yang tidak koperatif, b) ibu hamil diusia kehamilan trimester pertama atau kedua, dan 3) ibu hamil dengan indikasi patologis dan berisiko (penyakit cardiovaskuler, diabetes type-2 atau terdiagnosa GDM).

Penelitian dilakukan di wilayah kerja dua puskesmas di Dinas Kesehatan Kota Bukittinggi, yaitu; Puskesmas Mandiangin dan Puskesmas Rasimah Ahmad Kota Bukittinggi. Waktu penelitian terhadap sampel dilakukan selama 10 minggu dari Juli sampai September 2020. Izin penelitian didapatkan dari LPPM STIKES Perintis Padang melalui surat lolos kaji etik penelitian melibatkan manusia sebagai subjek yang dikeluarkan KEPK STIKES Perintis Padang. Selanjutnya izin pengambilan data dan penelitian dari KESBANGPOL dan Dinas Kesehatan Kota Bukittinggi.

Pemeriksaan jumlah asupan karbohidrat merupakan teknik pengukuran jumlah asupan karbohidrat gram/ hari (diperiksa dalam 1 minggu terakhir dengan flashback asupan/ food recall 7x24 jam) ibu hamil trimester ketiga. Pengukuran bertujuan untuk mendapatkan rerata asupan gr/hari dengan menggunakan aplikasi nutrisurvey. Penghitungan jumlah asupan karbohidrat (gram karbohidrat) dilakukan oleh anggota peneliti yang dianggap cakap dalam proses analisis survey nilai gizi. 
Pemeriksaan glukosa darah merupakan pengukuran kadar glukosa glikohemoglobin (HbA1c) pada ibu hamil trimester ketiga menggunakan metode HAPO karena hasil pemeriksaan ini menunjukan gambaran ikatan glikohaemoglobin ibu dalam 3 bulan terakhir. Pemeriksaan dilakukan pada usia kehamilan ibu antara 7-9 bulan (28-34 minggu) untuk menentukan kondisi normal (nilai $<5,7 \%$ ), prediabetes $(5,7-6,4 \%$ ), atau GDM (nilai $>6,4 \%$ ) yang akurat sebagai konfirmasi kepastian diagnosis yang belum pernah lakukan yang biasanya hanya menggunakan pemeriksaan OGT. Pengukuran glukosa dilakukan langsung oleh peneliti dan didampingi tenaga kesehatan (bidan) atau kader agar memiliki pengetahuan baru tentang pemeriksaan glukosa darah ibu hamil dengan HbA1c. Metoda ini dapat menjadi intervensi baru tenaga kesehatan puskesmas (terutama kader) dalam mengidentifikasi akurasi risiko dan pasti GDM. Pemeriksaan metoda HAPO dilakukan dengan menggunakan gluco-test Biohermes HbAlc tets device. Hasil pencatatan asupan karbohidrat tersebut dianalisis untuk ditentukan rerata asupan karbohidrat gram/hari, beseerta nilai persentasi kadar glukosa HbA1c.

Data dikumpulkan untuk dianalisa menggunakan program SPSS menggunakan analisa univariat tentang data persentase distribusi atau proporsi dari variabel usia ibu, jumlah asupan karbohidrat (gram harian), dan glukosa darah metoda HAPO HbA1c. Analisa Bivariat dalam penelitian ini menggunakan uji one-way ANOVA test dan korelasi. Variabel numerik penelitian adalah jumlah asupan gram karbohidrat, sedangkan variabel kategorik adalah nilai glukosa metoda HAPO HbA1c.

\section{HASIL PENELITIAN}

Tabel. 1

Karakteristik Sampel Berdasarkan Status Kehamilan dan Nilai HbA1c

\begin{tabular}{cccccc}
\hline Karakteristik & Indikator & $\mathrm{f}$ & $\%$ & Mean & Std. Deviation \\
\hline \multirow{5}{*}{ Gravida } & Pertama & 14 & 41.2 & 27.29 & 3.931 \\
& Kedua & 13 & 38.2 & 27.54 & 2.470 \\
& Ketiga & 6 & 17.6 & 31.17 & 3.189 \\
& Keempat & 1 & 2.9 & 35.00 &. \\
\cline { 2 - 6 } & Total & 34 & 100.0 & 28.29 & 3.656 \\
\hline \multirow{5}{*}{ HbA1c (\%) } & Normal & 10 & 29.4 & 5.51 & 0.07 \\
& Prediabetes & 23 & 67.6 & 5.95 & 0.19 \\
& GDM & 1 & 2.9 & 6.50 &. \\
\cline { 2 - 6 } & Total & 34 & 100.0 & 5.84 & 0.28 \\
\hline
\end{tabular}

Berdasarkan tabel 1 menunjukan bahwa 67\% sampel berada dalam kondisi prediabetes dan terkonfirmasi GDM (satu sampel) dimana sebelumnya kriteria sampel adalah ibu hamil tanpa riwayat DM dan dengan riwayat keluarga tanpa diabetes mellitus. Pemeriksaan pada ibu hamil juga mengidentifikasi riwayat kehamilan sampel yang pada umumnya ibu dalam kondisi kehamilan pertamanya $(41.2 \%)$ dan pada kehamilan keduanya (38.2\%). 
Tabel. 2

Signifansi Kejadian GDM Berdasarkan

Jumlah Asupan Karbohidrat Harian (Gram)

\begin{tabular}{lccccccc}
\hline Nilai HbA1c & $\mathrm{N}$ & $\%$ & Mean & $\begin{array}{c}\text { Std. } \\
\text { Deviation }\end{array}$ & Minimum & Maximum & p-value \\
\hline Normal & 10 & 29.4 & 139.9 & 27.3 & 102.0 & 196.9 & \\
Prediabetic & 23 & 67.6 & 192.5 & 24.1 & 119.5 & 229.6 & 0.000 \\
GDM & 1 & 2.9 & 245.0 &. & 245.0 & 245.0 & \\
\hline Total & 34 & 100.0 & 178.6 & 36.3 & 102.0 & 245.0 & \\
\hline
\end{tabular}

Berdasarkan tabel 2 menunjukan adanya pengaruh yang signifikan antara risiko kejadian GDM pada ibu hamil trimester 3 berdasarkan jumlah asupan karbohidrat harian (gram) dengan nilai perbedaan mean yang signifikan pada 0.000 (nilai $\mathrm{p}<0.001$ ). Dari tabel 2 dapat dilihat bahwa rerata jumlah asupan karbohidrat harian ibu hamil yang memiliki kondisi pre-diabetes adalah 192.5 \pm 24.1 gram. Sedangkan sampel yang terkonfirmasi GDM menunjukan jumlah asupan karbohidratnya sekitar 245 gram/hari.

\section{PEMBAHASAN}

Pemeriksaan $\mathrm{HbA1c}$ digunakan karena memiliki nilai sensitivitas 95.6\% dengan spesifisitas $51.6 \%$ dalam mendiagnosis GDM dibandingkan pengukuran menggunakan OGTT (oral glucose tolerant test). Pemeriksaan ini dapat secara akurat menskrining ibu hamil dengan risiko GDM pada trimester akhir kehamilannya (CS \& TC, 2020). Selanjutnya, penelitian (Dong et al., 2021) juga mengindikasikan meningkatnya risiko GDM ibu hamil dari jumlah makronutrien yang dikonsumsi ibu dalam 3 hari terakhir. Pemeriksaan tersebut menyatakan bahwa lemak total, protein total hewani, atau lemak hewani yang terutama berupa lemak jenuh (saturated fat) secara signifikan berkaitan langsung dengan terpicunya risiko abnormalitas regulasi glukosa darah selama kehamilan.

Hasil studi ini secara keseluruhan hanya mengidentifikasi jumlah gram asupan karbohidrat rerata harian ibu hamil tanpa membedakan sumber hewani dan nabatinya. Karakteristik lain sampel yang diteliti adalah usia ibu hamil saat diteliti berada pada rentang usia 22-35 tahun, kondisi overweight (50\%), dan status kehamilan ibu yang pada umumnya di kehamilan pertamanya (41.2\%). Hasil penelitian Stevanović-Silva juga menunjukan bahwa pemberian asupan dengan HFHS (high-fat-high-sucrose) selama 18 minggu secara berurutan pada percobaannya menunjukan peningkatan berat badan (overweight) sebagai karakteristik pencetus GDM (Stevanović-Silva et al., 2021).

Sampel penelitian mengalami kondisi pre-diabetes dimana nilai mean hasil pemeriksaan HbA1c menunjukan $5.84 \pm 0.28 \%$. Hal ini berbeda dengan penelitian (Sánchez-González et al., 2018) yang menunjukkan nilai rentang persentase HbA1c yang mereka temukan berada pada rentang $4.4 \%$ sampai $5.6 \%$ dibandingkan dari hasil penelitan ini yang berada pada $5.4 \%$ sampai $6.5 \%$. Selanjutnya, penelitian yang pernah peneliti lakukan dan juga merujuk dari beberapa hasil penelitian sebelumnya juga menunjukan adanya peranan pengetahuan, input informasi, asupan harina terutama karbohidrat dan lemak, dan ketahanan selama menderita diabetes melitus pasien terkonfirmasi akan memiliki signifikansi dengan gangguan-gangguan organ dan sistemik (Naeem et al., 2019; Sánchez-González et al., 2018; Suryati et al., 2019). 
Berdasarkan review CS \& TC (2020) menunjukkan bahwa cut-point dalam menentukan diagnosis diabetes adalah nilai $\mathrm{HbA1c} \geq 6.5 \%$. Nilai HbA1c pada ibu hamil trimester pertama mengalami penurunan yg cukup rendah dikarenakan adanya peningkatan sintesis eritrosit, selanjutnya, pada postpandial hyperglicemia dan peningkatan intoleransi karbohidrat pada trimester selanjutnya yang pada akhirnya menyebabkan meningkatnya nilai persentase HbA1c ibu hamil dimulai di trimester 2 dan lebih tinggi lagi di trimester ke-3. Ibu dengan indikasi memiliki nilai HbAlc yang tinggi selama kehamilan trimester akhir akan meningkatkan terjadinya macrosomia dan neonatal hypoglicemia. Kami memercayai bahwa meningkatnya asupan glukosa dan karbohidrat ibu selama kehamilan akan mengacu peningkatan risiko kejadian GDM yang ditandai tingginya sampel dengan prediabetes dari HbA1c, terutama screening yang tepat dilakukan pada usia kehamilan 24-28 minggu (awal trimester 3) (CS \& TC, 2020). Namun, hasil temuan Hasbullah et al., (2020) tidak menunjukan hubungan yang signifikan terhadap risiko GDM, tetapi semakin tingginya GI dan GL ibu hamil akan memicu berkembangnya faktor risiko GDM pada ibu hamil, terutama perawakan fisik rendah, asupan karbohidrat dan energi tinggi, dan diit rendah serat.

Dengan tingginya angka kejadian ibu hamil dengan prediabetes dari penelitian ini, kondisi ini dapat mencegah sedini mungkin comorbiditas kelahiran yang bermasalah. Jika ibu dengan nilai persentase glikohemoglobin tinggi (HbAlc > 6.4\%) menetap selama kehamilan, perkembangan kehamilan akan terbentuk komplikasi seperti; IUGR, microsomia, oligohydramnion, dan polyhydramnion. Selain itu, penelitian (Silva et al., 2021) dari 42 ibu hamil yang dilakukan pengukuran jumlah karbohidrat yang dikonsumsi dari produk ultra-procesed food (proses produksi bervariasi/ proses industrialisasi), didapatkan keterkaitan dengan terjadinya pre-gestational DM berdasarkan nilai energy (energy value-EV) dan total energy konsumsi harian.

Merujuk signifikansi dari yang kami temukan dengan hasil penelitian Rasmussen et al, terdapat adanya intervensi asupan tinggi karbohidrat tinggi di sarapan pagi sampel mamicu terbentuknya variabilitas glukosa darah yang tinggi dibandingkan pada sampel dengan asupan karbohidrat rendah di pagi hari. Namun, pemeriksaan sensitivitas insulin dari pemeriksaan glukosa plasma sesaat dan puasa sample menunjukan nilai yang mengacu kepada penurunan risiko GDM. Dibandingkan dari hasil penelitian yang dilakukan, pemeriksaan glikohemoglobin yang dilakukan memiliki sensitivitas yang sangat tinggi dalam mendiagnosis risiko GDM ibu hamil dibandingkan melalui pemeriksaan glukosa plasma. Kami meyakini, tingginya efektivitas dan sensitivitas pemeriksaan HbA1c dibandingkan pemeriksaan glukosa plasma akan sangat memengaruhi risiko terjadinya gangguan regulasi glukosa dalam darah dan sensitivitas insulin (Rasmussen et al., 2020). Hal ini sejalan dengan penelitian Naeem et al., (2019) bahwa pada pasien dengan diabetes mellitus tipe-2 yang diberikan OHA dan insulin, dimana terjadi perubahan nilai HbA1c karena intake karbohidrat dan jumlah kalori sehingga dapat menjadi predictor dalam peningkatan berat badan. Asupan karbohidrat harian dengan peningkatan nilai HbA1c juga (Ebe et al., 2017).

Wanita hamil memiliki kecendrungan yang signifikan terjadinya penurunan sensitivitas insulin seiring bertambahnya usia kehamilan. Adanya adaptasi sensitivitas insulin ini memacu gangguan regulasi glukosa darah ibu hamil dan memengaruhi sufisiensi sebaran nutrisi ibu hamil baik untuk dirinya maupun untuk perkembangan janinnya. Gestational diabetes mellitus (GDM) disebabkan oleh berkurangnya fungsi (disfungsi) sel- $\beta$ pankreas wanita hamil (umumnya berusia muda). GDM dikaitkan dengan adanya sedikit gangguan perinatal yang akan bermanifestasi pada peningkatan 
kejadian obesitas turunan dan risiko tinggi berkembangnya diabetes mellitus pada ibu dan anaknya. GDM diindikasikan ketika derajat intoleransi glukosa diakui untuk pertama kali selama kehamilan, terlepas dari apakah kondisinya telah mendahului kehamilan atau bertahan setelah kehamilan. Sekitar 1-14\% total kehamilan juga terdeteksi GDM (200.000 kasus lebih/ tahunnya). Modifikasi gaya hidup selama kehamilan dipercaya menurunkan risiko GDM (18\%) dimana karbohidrat harian secara signifikan berhubungan dengan nilai glukosa postprandial dan respon insulin selama kehamilan (Hasbullah et al., 2020; Rasmussen et al., 2020).

Hiperglikemia spontan merupakan komplikasi umum kehamilan dengan GDM. Perkiraan Diabetes Internasional Federation (2017), GDM mempengaruhi sekitar 14\% kehamilan di seluruh dunia, mewakili sekitar 18 juta kelahiran per tahun. Faktor risiko berupa obesitas, western diet dan defisiensi mikronutrien, usia ibu lanjut, dan riwayat keluarga resistensi insulin/ diabetes, aktivitas fisik yang inaktif, variasi genetic, polusi lingkungan, perawakan fisik rendah, etnis Asia, multiparitas, peningkatan berat badan selama kehamilan, pendapatan keluarga, dan status sosioekonomi. Walaupun GDM biasanya sembuh setelah persalinan, tetapi memiliki konsekuensi kesehatan jangka panjang yaitu risiko diabetes tipe-2 (T2DM) dan penyakit kardiovaskular (CVD) pada ibu, dan obesitas di masa depan, juga pada anak (Dong et al., 2021; Hasbullah et al., 2020).

Patogenesis utama oleh Plows et al., (2018) Pertama, Disfungsi $\beta$-Cell, kondisi disfungsi sel beta ( $\beta$-Cell) diperburuk karena adanya resistensi insulin. Pengurangan pengambilan glukosa yang distimulasi insulin lebih lanjut berkontribusi pada hiperglikemia, membebani sel-sel yang harus menghasilkan insulin tambahan sebagai respons. Kontribusi langsung glukosa terhadap kegagalan sel digambarkan sebagai glukotoksisitas. Dengan demikian, sekali disfungsi sel-sel dimulai, siklus setan dari hiperglikemia, resistensi insulin, dan disfungsi sel-sel selanjutnya mulai terjadi. Kedua, resistensi insulin kronis terjadi ketika sel-sel tidak lagi mampu berespon terhadap insulin. Pada tingkat molekuler, resistensi insulin biasanya merupakan kegagalan pensinyalan insulin, yang mengakibatkan translokasi membran plasma yang tidak adekuat dari transporter glukosa-4 (GLUT4) sebagai transporter primer yang bertanggung jawab untuk membawa glukosa ke dalam sel untuk digunakan sebagai energi.

\section{SIMPULAN}

Dua pertiga sampel penelitian berada pada posisi prediabetes, dan satu sampel dengan GDM. Hal ini membuktikan adanya keterkaitan asupan konsisten harian karbohidrat dengan nilai HbA1c yang mengacu kepada terjadinya status pre-diabetes dan diabetes gestasi pada ibu hamil trimester ketiga.

\section{SARAN}

Penelitian berikutnya dapat menganalisa status body mass index (BMI) ibu hamil di trimester 2 dan trimester 3 terhadap risiko terjadinya GDM. Selain itu pemeriksaan tidak hanya terbatas pemeriksaan berdasarkan ikatan glukosa di hemoglobin (glikohemoglobin) saja, melainkan pemeriksaan untuk melihat struktur eritrosit untuk melihat seberapa kuat ikatan glukosa dengan hemoglobin tersebut, sehingga dapat dilakukan penelitian lanjutan untuk melepaskan ikatan gliko-hemoglobin tersebut pada ibu hamil yang terindikasi prediabetes dan GDM positif. 


\section{DAFTAR PUSTAKA}

CS, L., \& TC, A. (2020). HbA1c in the Diagnosis and Management of Diabetes Mellitus: An Update. Diabetes Updates, 6(1). https://doi.org/10.15761/du.1000137

Dong, H., Sun, H., Cai, C., Pang, X., Bai, D., Lan, X., Zhang, Y., Zhang, J., \& Zeng, G. (2021). A Low-Carbohydrate Dietary Pattern Characterised by High Animal Fat and Protein during the First Trimester is Associated With an Increased Risk of Gestational Diabetes Mellitus in Chinese Women: A Prospective Cohort Study. British Journal of Nutrition, 18, 1-22. https://doi.org/10.1017/S0007114521000611

Ebe, K., Bando, H., Yamamoto, K., Bando, M., \& Yonei, Y. (2017). Daily Carbohydrate Intake Correlates with HbA1c in Low Carbohydrate Diet (LCD). $J$ Diabetol, 1(1), 4. http://www.alliedacademies.org/journal-diabetology/

Hasbullah, F. Y., Mohd Yusof, B. N., Shariff, Z. M., Rejali, Z., Yong, H. Y., \& Mitri, J. (2020). Factors Associated with Dietary Glycemic Index and Glycemic Load in Pregnant Women and Risk for Gestational Diabetes Mellitus. International Journal of Food Sciences and Nutrition, 71(4), 516-524. https://doi.org/10.1080/09637486.2019.1686752

Mariana, D., Wulandari, D., \& Padila, P. (2018). Hubungan Pola Makan dengan Kejadian Anemia pada Ibu Hamil di Wilayah Kerja Puskesmas. Jurnal Keperawatan Silampari, 1(2), 108-122. https://doi.org/10.31539/jks.v1i2.83

Naeem, N., Basit, A., Shiraz, A., Bin Zafar, A., Mustafa, N., Ali Siddique, S., \& Fawwad, A. (2019). Insulin-associated Weight Gain in Type 2 Diabetes and Its Relation with Caloric Intake. Cureus. https://doi.org/10.7759/cureus.5275

Plows, J. F., Stanley, J. L., Baker, P. N., Reynolds, C. M., \& Vickers, M. H. (2018). The Pathophysiology of Gestational Diabetes Mellitus. In International Journal of Molecular Sciences, 19(11). https://doi.org/10.3390/ijms19113342

Rasmussen, L., Christensen, M. L., Poulsen, C. W., Rud, C., Christensen, A. S., Andersen, J. R., Kampmann, U., \& Ovesen, P. G. (2020). Effect of High Versus Low Carbohydrate Intake in the Morning on Glycemic Variability and Glycemic Control Measured by Continuous Blood Glucose Monitoring in Women with Gestational Diabetes Mellitus-A Randomized Crossover Study. Nutrients, 12(2), 475. https://doi.org/10.3390/nu12020475

Sánchez-González, C. M., Castillo-Mora, A., Alvarado-Maldonado, I. N., OrtegaGonzález, C., Martínez-Cruz, N., Arce-Sánchez, L., Ramos-Valencia, M., MolinaHernández, A., Estrada-Gutierrez, G., Sosa, S. E. Y., Recio-López, Y., Hernández-Sánchez, R., \& Reyes-Muñoz, E. (2018). Reference Intervals for Hemoglobin A1c (HbA1c) in Healthy Mexican Pregnant Women: A CrossSectional Study. BMC Pregnancy and Childbirth, 18(1). https://doi.org/10.1186/s12884-018-2057-x

Silva, C. F. M., Saunders, C., Peres, W., Folino, B., Kamel, T., Dos Santos, M. S., \& Padilha, P. (2021). Effect of Ultra-Processed Foods Consumption on Glycemic Control and Gestational Weight Gain in Pregnant with Pregestational Diabetes Mellitus Using Carbohydrate Counting. PeerJ, 9(1), e10514. https://doi.org/10.7717/peerj.10514 
Stevanović-Silva, J., Beleza, J., Coxito, P., Pereira, S., Rocha, H., Gaspar, T. B., Gärtner, F., Correia, R., Martins, M. J., Guimarães, T., Martins, S., Oliveira, P. J., Ascensão, A., \& Magalhães, J. (2021). Maternal High-Fat High-Sucrose Diet and Gestational Exercise Modulate Hepatic Fat Accumulation and Liver Mitochondrial Respiratory Capacity in Mothers and Male Offspring. Metabolism: $\begin{array}{llll}\text { Clinical and } & \text { Experimental, } & 116, & 15404 .\end{array}$ https://doi.org/10.1016/j.metabol.2021.154704

Suryati, I., Primal, D., \& Pordiati, D. (2019). Hubungan Tingkat Pengetahuan dan Lama Menderita Diabetes Mellitus (DM) dengan Kejadian Ulkus Diabetikum pada Pasien DM Tipe 2. Jurnal Kesehatan Perintis (Perintis's Health Journal), 6(1), 1-8. https://doi.org/10.33653/jkp.v6i1.214 